\title{
Research Paper: The Role of Rural Tourism in Sustainable Rural Development: A Case Study of Shandiz Rural crossark Region, Khorasan Razavi Province, Iran
}

\author{
Reihaneh Soltani Moqadas $^{1^{*}}$
}

1. Assistant professor, Department of Geography, Payame Noor University, Tehran, Iran.

\begin{tabular}{|c|c|}
\hline $\begin{array}{l}\text { Use your device to scan } \\
\text { and read the article online }\end{array}$ & Citation: Soltani Moqadas, R.. (2018). The Role of Rural Tourism in Sustainable Rural Development: A Case Study of \\
\hline 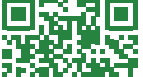 & $\begin{array}{l}\text { Shandiz Rural Region, Khorasan Razavi Province, Iran. Journal of Sustainable Rural Development, 2(1-2), 61-76. https://doi. } \\
\text { org/10.32598/jsrd.01.03.280 }\end{array}$ \\
\hline$\square$ ard & doi : https://doi.org/10.32598/jsrd.01.03.280 \\
\hline
\end{tabular}

\section{Article info:}

Received: 07 April 2018

Accepted: 15 July 2018

\section{Keywords:}

Rural tourism, Economic diversification, Local investment, Sustainable rural capacity building, Entrepreneurship, Rural sustainability

\begin{abstract}
A B STRACT
Purpose: Owing to the vital role of rural tourism in the resurgence of rural economies, rural settlements have been encouraged to incorporate it into their local economies. This paper examines the rural settlements around the metropolitan city of Mashhad in the northeast of Iran to determine the role of tourism in creating sustainable economic capacities in rural areas.

Methods: The data were collected through a field study of 237 selected households to evaluate the research variables. Two models were applied to test the hypotheses.

Results: It is shown that there are relationships among the variables and that rural tourism can lead to the expansion of sustainable capacities through economic diversification, entrepreneurship, and the production of local capital. Indeed, rural tourism is found as a central phenomenon that can create new opportunities in rural settlements.
\end{abstract}

Conclusion: Rural tourism indirectly promotes rural sustainability. The promotion of diverse economic sectors is highly significant for building rural sustainable capacities.

\section{Introduction}

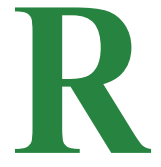

ural settlements in developing countries have been experiencing numerous problems because of diminished economic and vocational capacities and increased destruction of natural resources, particularly of agricultural lands (Mwesigye
\& Matsumoto, 2016; Abubakari et al., 2016; Demetriou, Stillwell \& See, 2013; Myers, 2003). These conditions have led to an increase in migration. Similarly, some rural settlements in Iran have suffered from horrendous economic instability over the past decades (Taleshi \& Amirfakhrian, 2011; Soleimani et al., 2015). As in most rural areas, the economy has declined to a point where the income from traditional agricultural activities has 
fallen below the average per capita income. To partially cope with the problem, tourism has come to be considered as a major factor in the development of countries (Hesam \& Rezvani, 2017). This is because it can encouraging capacity building in various complementary activities (Biddulph, 2015; Frisvoll, 2012). With regard to the various geographical and historical landmarks located in Iran, this study focuses on the country's potential for tourism development. Tourism is considered as a means of planning development and solving rural problems through building capacities, which is its most notable effect. Rural tourism can be developed based on local resources and competencies. This can lead to sustainable capacity building which, in turn, guarantees self-reliance and endogenous social improvement. Indeed, it has a pivotal role in development (Zasada et al., 2015). Dyer et al. (2007) state that the development of rural tourism as an economic activity is a relatively new phenomenon compared with other rural economic activities. However, it can be a major source of income for villagers, a motivation for their permanent settlement in villages, and a way to increase spatial relationships (Dyer et al., 2007; Tosun, 2002; Gursoy \& Deny, 2003; Nourozifard $\&$ Khorasani, 2016). These merits create new attractions and capacities in rural areas which are accompanied by residual values and economic benefits for local residents.

In tourism-oriented rural planning, the link between local and non-local economies enhances the capacities of society, benefits the poor, and subsequently reduces poverty (Ashley, Roe, \& Goodwin, 2001; Cater, 1987; de Kadt, 1979; Mitchell \& Ashley, 2010). According to Hernandez, Suarez-Vega, and Santana-Jimenez (2016), tourism can lead to both socioeconomic changes and economic diversity. Tourism planners and policymakers, thus, make efforts to promote rural capacities. Any policymaking process for rural tourism should establish a solid connection between regional and non-regional markets, which can divert an increased proportion of economic interests to the local population (Sharpley, 2002; Bramwell, 2004).

During the 1990s, European organisations encouraged the development of tourism in various rural areas. Initially, Europe emphasized rural tourism by paying due attention to agricultural problems and resource-driven crises and then by focusing on the establishment of new economic sectors in villages and rural settlements. Therefore, rural tourism is proposed as a contemporary version of tourism that is developing in Europe (Campón-Cerro et al., 2016; Blanco, 1996).
Tourism has been promoted as one of the most important economic and socio-cultural phenomena in the world. Currently, rural tourism is becoming more valuable because of its diverse potentials and, thus, crucial for both rural and urban residents. According to Bianchi (2004), sustainable development has been established as the prevailing paradigm of tourism policy, planning, management and research (Bianchi, 2004; Torres-Delgado \& Saarinen, 2014). Additionally, Ezeuduji (2015) states that 'Sustainable rural development encourages locals to embark on initiatives that will help their socioeconomic development and, at the same time, protect their environment' (Ezeuduji, 2015, p. 214).

Rural settlements face a number of challenges posed by economic instability, including limited job opportunities as well as the shortage of economic capacities. Rural tourism can serve as a means of facing those challenges. One of the visualized roles of rural tourism is to improve economic capacity despite multiple implementations required to recognize the natural potential and socioeconomic opportunities of rural regions and the long-term planning process for sustainable development. This study aims to investigate the significance of rural tourism in Shandiz rural sector in eastern Iran and explore the sustainable capacity building in this rural area. This region possesses diverse environmental potentials, making it a suitable location for tourism investment and revitalization of the natural capacities of the region (Anabestani \& Vesal, 2016). While Iran has undergone farming restrictions in recent decades, tourism has played a major role in the suburban areas of Mashhad in eastern Iran. It has influenced the national and regional conditions as well as created capacities in transnational contexts, thereby ensuring the sustainability of the settlement system.

\section{Literature Review}

This section discusses the recent relevant literature on rural tourism and presents an integrated model to illustrate the advantages of rural tourism and economic capacity-building concepts.

\subsection{Rural tourism and rural sustainable}

Beginning in the 1960s, tourism developed from a relatively small-scale activity into a global economic phenomenon. The potential of tourism to generate economic development has been largely accepted as axiomatic. National governments view tourism as a source of employment and a means of generating income, earning foreign exchange and bringing wide economic benefits to regions with otherwise limited economic potential 
(Zeng, 2015). Crotts and Holland (1993) state that, when the level of tourism activities increases, the per capita income of permanent residents rises too. This seems in contrast with the widely-held assumption that tourism only provides low-income jobs for residents. As the authors believe, tourism provides sources of income and increases the earnings of average residents.

It is widely assumed that tourism can help eliminate the growing economic gap between the developed and the so-called majority world, where the majority of the world's population live in poverty (Burns \& Novelli, 2007; Harrison, 2001; Mowforth \& Munt, 2009; Sharpley \& Telfer, 2015; Telfer \& Sharpley, 2008). In addition, tourism is a viable option for the sustaining of remote, relatively isolated communities. In areas suffering from economic decline, where there are few alternatives, cultural rural tourism may serve as a lifeline (Hall, Kirkpatrick \& Mitchell, 2005).

Undoubtedly, Tourism is a key sector in the sustainable development of rural environments. Its ability to create stable employment and an acceptable level of profts is conditioned by the stability of tourist activity throughout the year (Guaita Martínez et al., 2019). Also, it is a valuable source of foreign currency earnings, and, as a service sector, it may reduce inflationary tendencies. Tourism generates employment opportunities, new investment, new sources of income and governmental revenues, and finally, creates earnings through the exploitation of the host country's natural and cultural attractions in addition to promoting environmental protection and care (Sharpley \& Telfer, 2015).

Tourism has, therefore, become a tool for economic development in some countries, contributing to the improvement of the standards of living (Sanchez-Rivero \& Cardenas-Garcia, 2014). A positive aspect of tourism is that it is one of the most labour-intensive industries and, therefore, has the potential of job creation and economic development in rural areas; indeed, it is often seen as the linchpin in many rural development strategies (Hall, Kirkpatrick, \& Mitchell, 2005). For example, in Malaysia, the tourism sector is the third largest revenue-generating industry after the oil and gas and manufacturing sectors (Lo, Mohammad, Songan \& Yeo, 2012; Nair, Munikrishnan, Rajaratnam, \& King, 2015).

Apart from the increase in the capacity and profits that individual firms, in specific, and the tourism sector, in general, can achieve from successful investment, there are certain perceived national and regional benefits that may come from a more favourable tourism investment, including economic growth, job creation, utilisation of domestic resources particularly renewable resources, skill acquisition, expansion of exports, development of remote areas of the country, and facilitation of ownership through individual investment (Dwyer, Forsyth \& Papatheodorou, 2011).

Because of the decrease in the rate of economic development, fragile economic situations, low level of life quality, and deficiencies in infrastructures and services, rural regions of developing countries are faced with several limitations particularly for their economic development. As such, considering local resources, new alternatives should be worked out to tackle the problem (Zamora, 2011). Holland et al. (2003) assume rural tourism as a proper alternative to maintain rural stability.

In this regard, rural tourism is a new type of activity characterized by small, scattered establishments located in the countryside (Cantallops, Cardona, \& Muntaner, 2015). Scholars favour rural tourism as an economic tool for regional development (Sharpley \& Telfer, 2015). Also, it provides a valuable source of employment and income for society members and alleviates destitution (Ryan, Gu, \& Zhang, 2009). rural tourism is sometimes propounded as a mechanism for spatial economic restructuring to lessen regional discrepancies and to enhance the economic independence of low-income people (Liu, 2006; Jafaar, Rasoolimanesh \& Tuan Lonik, 2015). Likewise, Butler and Hall (1998) state that 'for rural areas to be sustainable, the range of associated activities must be integrated and coordinated' (p. 249). Saxena, Clark, Oliver, and Illbery (2007) hold that integrated rural tourism, which links tourism to 'the economic, social, cultural, natural and human structures' of the destination, can facilitate sustainable tourism (see also Fennell, 2008). In this case, Saxena et al. (2007) suggest that 'such a development creates powerful network connections between tourism and local and regional resources, activities, products and communities' (p. 347).

Rural tourism industry has been experiencing a rapid change. It is to fulfil expectations through contribution to rural development processes and to emerge as an industry of sustainable and growing businesses. It brings productivity and economic revitalisation (Ilbery, 1998; Napton, Walford, \& Everitt, 1999; Hall, Kirkpatrick \& Mitchell, 2005; Anderson, Bakir, \& Wickens ,2015).

As an example of high expectations, rural tourism in Malaysia is strongly emphasized as part of the national rural development agenda to create employment op- 
portunities, increase income levels and reduce poverty among rural people, who comprise $37 \%$ of the total population (Nair, Munikrishnan, Rajaratnam \& King, 2015). In Canada, rural tourism is generally seen as a viable economic option, in addition to traditional activities, that can serve in many peripheral regions as an appropriate tool for economic rejuvenation, particularly in remote northern regions and the Atlantic provinces (Weaver, 2001; Jenkins \& Parrott, 1997). Moreover, in destinations such as Ireland, tourism has particular significance for peripheral rural areas where agriculture has declined. It has undergone rapid socio-economic and environmental changes over the last 20 years. Irish tourism is highly dependent on the quality of the natural environment, and images of a clean and green environment are ubiquitous in its promotional materials (Cawley, Gaffey \& Gillmor, 2002; Deegan \& Dineen, 2003). In this regard, Anderson et al. (2015) note that 'in Ireland, the policy during the 1970 s and 1980s was to invest in agriculture in peripheral areas to support rural economic growth. Tourism began to see direct investment from the late 1980s, mainly as a result of a lack of alternative investment opportunities in the face of high unemployment and a history of emigration in peripheral areas, including Connemara' (p. 78). According to Ezeuduji (2015), rural tourism has contributed to rural sustainability in some parts of Africa.

\subsection{The importance of capacity building}

The term "capacity" involves the idea of containing in the sense of holding and storing as well as the idea of being able to think and act. When a community focuses on capacity building, that community is assumed to have specific capabilities to act in certain ways or to do certain things. In a community, capacities are built as a means of improving or maintaining the well-being of all the individuals, informal groups, organisations, social networks, and the physical environment there (Chaslzin et al., 2001). In other words, capacity building implies the idea of creating certain potentials. When a community has a specific capacity, it has potentials to do, obtain, or accomplish specific things, although those things may not be well-defined yet. When capacity building becomes a priority, the community is presumably acting in a less-than-optimal level at present, and it needs external help to actualize its potential and to improve in general (Kenny \& Clarke, 2010). The capacity of a community includes 'all the assets and attributes that a community can use in order to enhance the people's lives' (Lavarack, 2006, p. 267). Furthermore, the capacity of a community can be defined as the ability of individuals and organisations there to manage their affairs and work collectively to promote and maintain positive changes
(Hounslow, 2002). From this perspective, the abundance of natural resources is not the factor to determines the ability of a society to institutionalize economic development and to achieve social progress. In this regard, the capabilities of people, institutions, and organisations are the major factors that should be considered. For instance, Africa has abundant natural resources, but, due to lack or inefficiency of human activities, those resources have remained passive in many parts of the continent. Generally, people's skills, ideas, knowledge, innovation, creativity, talent, institutions (e.g., economic, social, and political ones), and organisations (i.e., both public and private ones) represent the capacity of a community (James, 1998). Once people receive education, wherein certain knowledge and skills are transferred to them, and enjoy local participation and control, capacity building can ensue to enrich their lives. At present, the idea of capacity building should be considered in all development endeavors (Kenny \& Clarke, 2010). Policymakers should be aware of the value of local capacity building (Plummer \& Taylor, 2004) to enable rural people to apply their resources innovatively to create new assets. Capacity building determines their direction, specifies their priorities, and significantly leverages both internal and external resources for their present community. This approach helps communities address challenges and assist the individuals and families that reside there (Murty, 2004; Scales, Streeter, \& Cooper, 2014).

\subsection{Rural tourism and sustainable capacity build- ing}

Owing to its significant contribution to rural sustainability, tourism plays a vital role in capacity building in the rural economy (Lopez \& Pastor, 2015). Due to the lack of economic units and proper job opportunities in rural areas, many young people tend to migrate to urban areas, which eventually leads to rural unsustainability (Hoefle, 2016). To enjoy sustainable rural development, policymakers must take sustainable capacity building into account and take measures to attain the goals of rural planning through it.

Creating a link between rural and urban areas is a practical step toward taking the required measures in the rural areas that surround metropolises. This attracts a plenty of tourists and results in economic benefits and value added. The relative spatial advantage of rural settlements is achieved when they are located in places where activities relevant to adjacent cities can be easily done. Various tourist attractions located in big cities, where innumerable environmental problems are present, 
have motivated the growth of mass tourism in potential rural areas around these megacities.

In addition, rural tourism can enhance the current economic capacities in the industrial and service sectors. Various capacity building programs, which are likely to be implemented in rural areas, involve service units, small construction companies, job opportunities in the second houses of urban residents, and jobs in small local restaurants. In this case, the benefits of sustainable capacity building can be enumerated and discussed as follows:

Economic diversification: One of the effects of rural tourism on capacity building is the diversification of the economy. Economic diversification plays an important role in the stability of rural development (Gautam \& Andersen, 2016). In addition, economic diversification in rural areas can help overcome various challenges in these regions and eventually lead to financial capacity building for rural families. Many of these families have numerous problems in their villages due to dependence on agriculture as the dominant economic mode (Gautam \& Andersen, 2016; Reardon et al., 1992).

Establishing industrial workshops for the production of goods (Martin \& Lorenzen, 2016), fish farming and beekeeping, which inspire tourists to buy and demand more goods, are the other advantages of capacity building in rural tourism (Hwang \& Lee, 2015).

Development of new services: All the service units developed on the basis of tourism are small in scale. They are mostly managed by families and considered as selfemployment (Helmi Ali \& Suleiman, 2016; Steiner \& Atterton, 2015). For example, during an investigation of ecotourism stakeholders in Belize, Kroshus Medina (2005) revealed that local people prefer self-employment in tourism rather than waged labor (i.e., they chose to be entrepreneurs rather than employees). This is because of the benefits derived from the former in comparison to the latter (Fennell, 2008; Kroshus Medina, 2005).

Selling local agricultural crops: From the perspective of agritourism, selling local goods to tourists is recognized as a part of rural business, which brings much benefit for villagers. Unlike the traditional approach in which indirect sales are encouraged and added value is nominal, in agritourism, agricultural crops are sold directly with no intermediate agents involved (Gil Arroyo et al., 2013; Flanigan et al., 2014). This type of tourism promotes agricultural and conversional activities and generates opportunities for farmers to create new markets and succeed in their local marketing efforts (Tew \& Barbieri, 2012; Naidoo \& Sharpley; 2016; Garrod et al., 2006).

Establishment of restaurants and cafeterias: One of the activities that are encouraged to diversify the economy in rural settlements is establishing restaurants and cafeterias operated as family businesses. As these service units are created in natural rural environments, such as in gardens, with minimal investment, they can provide a desirable value added for the villagers (Démurger et al., 2010).

Rural entrepreneurship: Lack of job opportunities in rural areas is considered as one of the problems that result in economic instability. Thus, capacity building in entrepreneurship is a major manifestation of capacity building in rural tourism activities. Many tourism-related jobs are developed in rural settlements; for instance,small businesses for young village residents (Moscardo, 2008). Entrepreneurship also contributes to change through invention or conversion that generally yields risk, thereby highlighting the opportunities to create and operate businesses and organisations (Zhao et al., 2011). Moreover, entrepreneurship has a notable effect on the transformation of tourist cenetrs (Russell \& Faulkner, 2004), once rural entrepreneurs seek innovative concepts or opportunities to establish new businesses (Bygrave, 1993). Such an approach clarifies the influence of entrepreneurs on the development of tourism. Russell and Faulkner (1999) observed a significant relationship between innovative individuals (i.e., entrepreneurs) and the development of tourist destinations. Thereafter, entrepreneurship can lead to the preservation of rural financial and intellectual capital and to the acceleration of rural development (Chemin, 2008).

Development of local assets: Local assets play an important role in rural sustainability because they can create new job opportunities for rural inhabitants. Rural tourism affects the expansion of local assets which are achieved through various rural activities and can be effective in sustainable capacity building. Drawing upon the economic proliferation and the development of local assets, local people are able to increase their income, which affects their welfare significantly (Zhang et al., 2016; Haase Svendsen et al., 2010). Sustainable capacity building in tourism can attract urban investments as well. Macro investment in urban areas develops tourist sites and their specific activities by creating services and small chain activities for rural inhabitants, thereby contributing to capacity building in rural areas (Zasada \& Piorr, 2015). Therefore, rural tourism plays an important role in wealth aggregation through capacity building and 
developing a unique identity for rural settlements (Silva \& Leal, 2015). If tourism becomes a viable means of earning more money, rural residents might be more motivated to participate in tourism development (Ghanian et al., 2017). Furthermore, the capacity building compatible with environmental capabilities and geographical amenities is the most optimal type of planning for rural sustainability (Moloney \& Fünfgeld, 2015). From an operational perspective, significant variables with which to measure rural tourism are the number of tourists and the tourist units (Ionela et al., 2015).

\section{Methodology}

The paradigm of this research is based on the functionalist theory with a regional network and a cause-effect approach ( $\mathrm{Li}$ et al., 2016). The interrelationship of the variables is determined by two tests and models. The one-sample Kolmogorov-Smirnov test is conducted on the data to determine what is normal. Structural Equation Modelling (SEM) with PLS and parametric tests are used to analyze the logical relationship among the variables. SEM encompasses 'a broad array of models from linear regression to measurement models to simultaneous equations, including confirmatory factor analysis (CFA), correlated uniqueness models, latent growth models, multiple indicator and multiple cause (MIMIC) models, and item-response theory (IRT) models. SEM is not an estimation method for a particular model as much as it is a way of thinking, of writing, and of estimating' (StataCorp, 2011, p. 2). In order to specify the cause and effect relationship, Structural Equation Model (SEM) was applied with the PLS software. Through this investigation, the reciprocal relationships among various factors were examined to shed light on their contribution to capacity building for rural settlmets. To verify the research hypothesis, the type and the domain of the reciprocal relationships among the variables were analysed, and the research model was proposed based on the research findings. According to this hypothesis, cities create many reciprocal economic values in rural centers. The research pursues a descriptive-analytic method using library work, interviews and questionnaires. The required data were partly collected through interviews with rural inhabitants and the owners of services and industrial units in the selected villages. Also, following the research principles, a Likert questionnaire was designed and given to the participants of this study. The researchers kept visiting the selected rural areas for five months to gather the data.

The studied region has a population of 30,972. Based on Cochran's sampling formula, 327 persons were se- lected as the participants of the study. In the qualitative part of the research, about two thirds $(60 \%)$ of the participants were men and the rest were women. Since this study mainly focused on village residents who had a job, most of the participants were male. Almost half of the participants (49\%) were below 30 years of age $43 \%$ of whom were average waged workers. As for the level of education, more than half of the participants $(56 \%)$ had a diploma, and $11 \%$ had a bachelor's degree. In terms of employment, two thirds of the participants $(66 / 8 \%)$ were working in the agricultural sector, whereas one third $(33 / 2 \%)$ were in the non-agricultural sector such as industry and services (Table 1).

Some hypotheses are suggested to aid in selecting the variables. Hypothesis one examines the impact of rural tourism on economic diversification, which is an index of sustainable capacity building. Hypothesis two examines the impact of rural tourism on entrepreneurship as determined by two variables. Hypothesis three examines the influence of rural tourism on the production of local investment. Hypothesis four studies the relationship between rural tourism and rural sustainability via economic capacity building, rural satisfaction, increased revenue, and welfare. Also, several indices and variables are chosen to test the impact of rural tourism on the sustainable capacity building of Shandiz, as illustrated in Table 2 .

This study was conducted in the province of Khorasan Razavi in the northeast of Iran. The specific study site was Shandiz region, which is located in the west of Mashhad metropolis, the second largest city in Iran. Mount Binalud is the most important landmark in this region; it plays a central role in offering unique landscape that motivates tourists and urban residents to visit local villages. The region can be considered as a microclimate compared with the surrounding semi-arid climate, thereby exhibiting the best features for a tourist region. It also possesses various unique natural-geographical features such as rivers, forests, dense vegetation, four distinct seasons, and favorable climate in winter, as shown in Figure 1. Since urban areas face many environmental challenges (e.g. air pollution and undesirable weather), this rural sector serves as an alternative and offers a wide range of capabilities to citizens who are typically deprived of a natural environment in cities. Thus, Mount Binalud can be regarded as an ideal tourist region. Another important characteristic of this region is its fertile land to produce nationally-known high-quality farming crops and garden products. There are also other villages in the region considered as tourist resorts owing to their rich natural resources and proximity to Mount Binalud Mountain. Since these villages are in the vicinity of 
Mashhad city and enjoy clean air, a large number of city residents travel there to enjoy picturesque scenery during holidays. The outstanding tourism-potential villages selected as the focus of the current study were Zoshk, Abarde Olia and Abarde Sofla, and Veirani. These villages have the utmost natural potential to attract citizens from Mashhad city. Demands for houses to buy there is a growing trend among urban dwellers who want a different place for their weekends or holidays. In addition, because a number of foreign tourists from Arab countries visit the region to enjoy its pleasant climate, tourist services have improved in the villages and towns there. The considerable number of tourists in the region actually boost the regional economy by playing a pivotal role in creating markets and economic opportunities for the villages.

\section{Findings}

Tourism can increase sustainable capacity building (ECB) in rural settlements. In this case, the potentials of every village may influence the regional economy. The variables in this study were examined in a statistical model to evaluate their influences.

Table 1. Demographics of rural residents as a case study
According to the descriptive statistics, as in Table 3, the independent variable 'welfare' has the highest mean of 2.79, while 'rural satisfaction' has the lowest mean of 2.27. The standard deviation of the 'local investment' variable is 0.91 higher that those of the others. To distinguish normal results, the one-sample KolmogorovSmirnov test was used. SEM parametric tests were then used for the data analysis (see Table 4).

Structural equations had to be tested using two models. The first model was the measurement model for the latent variables. Generally, this model shows that the observed factor loadings (factors) for each variable are hidden. After verification, the model was evaluated by calculating the structural equations, as shown in Figure 2.

The 'local investment' variable impacted entrepreneurship at a significance level of 0.22 , and the effect of sustainable capacity building on 'rural satisfaction' was found to be 0.23 . The corresponding hypothesis was, therefore, rejected, and the relationship was excluded from the model. The measurement model is shown as Figure 3 .

As another calculation, fit indices were determined for the proper diagnosis of the model. The fit index CMIN/

\begin{tabular}{cccc}
\hline Variable & Category & Number & Valid percentage \\
\hline \multirow{2}{*}{ Gender } & Male $=142$ & 142 & $60 \%$ \\
& Female $=95$ & 95 & $40 \%$ \\
Age & $20-30$ & 26 & $11 \%$ \\
& $30-40$ & 90 & $38 \%$ \\
& $40-50$ & 57 & $24 \%$ \\
Income level & $50-60$ & 52 & $22 \%$ \\
& +60 & 12 & $5 \%$ \\
& Below average & 88 & $37 \%$ \\
Average & 96 & $42 \%$ \\
& Above average income & 57 & $24 \%$ \\
& Below diploma & $53 \%$ \\
& Diploma & 78 & $36 \%$ \\
& Bachelor & 133 & $11 \%$ \\
& Farmer & 26 & $60 \%$ \\
& Non-farmer & 142 & $40 \%$ \\
\hline
\end{tabular}


Table 2. Model indicators

\begin{tabular}{|c|c|c|}
\hline Index & Indicators & Variables \\
\hline Rural tourism & & $\begin{array}{l}\text { The tourist attractions } \\
\text { The number of tourist buildings }\end{array}$ \\
\hline \multirow{3}{*}{$\begin{array}{l}\text { Sustainable } \\
\text { capacity building }\end{array}$} & $\begin{array}{l}\text { Economic } \\
\text { diversification }\end{array}$ & $\begin{array}{l}\text { The number of industrial workshops } \\
\text { The amount of fishing and bee gardening } \\
\text { The number of new services } \\
\text { Local sale of agricultural products } \\
\text { The number of restaurants \& cafés }\end{array}$ \\
\hline & Entrepreneurship & $\begin{array}{l}\text { The amount of job creation } \\
\text { The number of new activities }\end{array}$ \\
\hline & Production of local capital & $\begin{array}{l}\text { The amount of local investment } \\
\text { The number of local investors }\end{array}$ \\
\hline & Increase revenue & \\
\hline & Rural satisfaction & \\
\hline & Welfare & \\
\hline
\end{tabular}

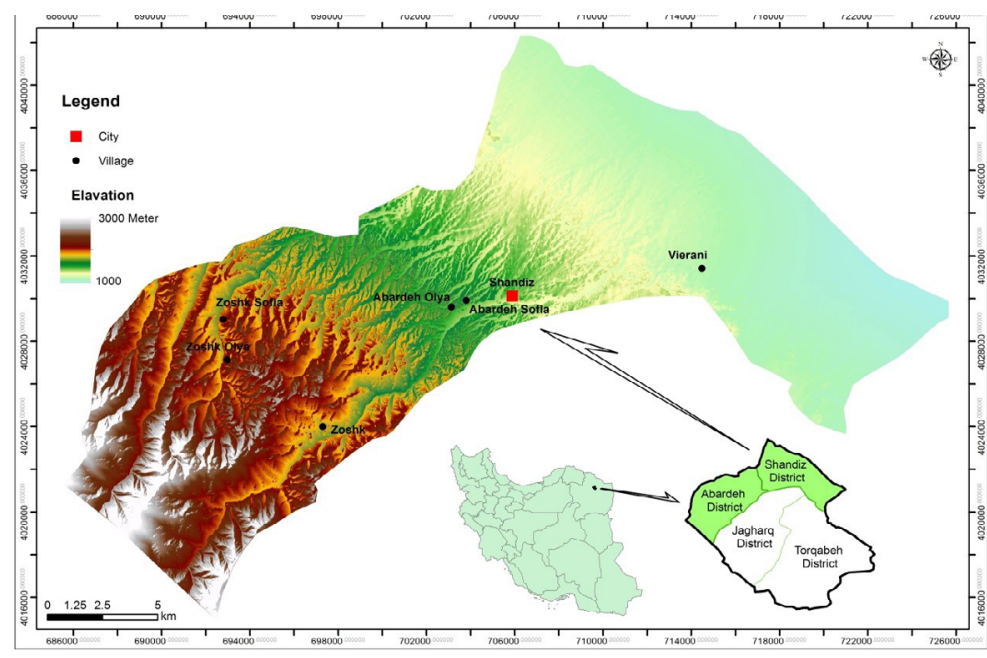

Figure 1. The geographical location of Shandiz region

Table 3. Statistical description

\begin{tabular}{|c|c|c|c|c|c|c|c|c|c|}
\hline $\begin{array}{l}\text { Statistical } \\
\text { description }\end{array}$ & 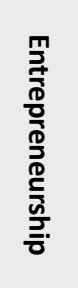 & 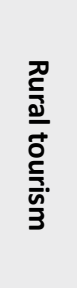 & 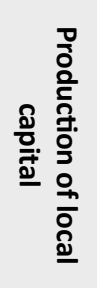 & 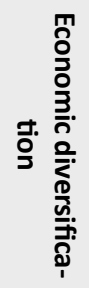 & 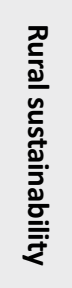 & 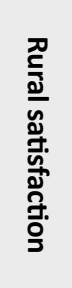 & 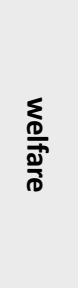 & 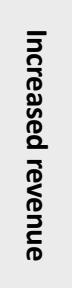 & 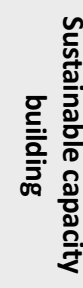 \\
\hline Mean & 2.60 & 2.78 & 2.49 & 2.42 & 2.53 & 2.27 & 2.63 & 2.49 & 2.39 \\
\hline Mode & 2.00 & 3.00 & 3.00 & 2.40 & 3.00 & 2.00 & 3.00 & 2.00 & 3.00 \\
\hline SD & .66 & .70 & .91 & .44 & .73 & .75 & .81 & .76 & .68 \\
\hline Minimum & 1.50 & 1.00 & 1.00 & 1.70 & 1.00 & 1.00 & 1.00 & 1.00 & 1.00 \\
\hline Maximum & 3.50 & 4.00 & 4.00 & 4.00 & 3.33 & 4.00 & 4.00 & 4.00 & 4.00 \\
\hline
\end{tabular}


Table 4. One-sample Kolmogorov-Smirnov test

\begin{tabular}{|c|c|c|c|c|c|c|c|c|c|}
\hline Test & $\begin{array}{l}\text { m } \\
\frac{1}{7} \\
\frac{1}{0} \\
\frac{0}{0} \\
\frac{9}{0} \\
\frac{0}{5} \\
\frac{5}{0} \\
\frac{\bar{n}}{0}\end{array}$ & 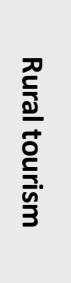 & 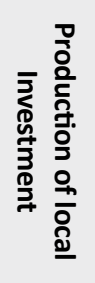 & 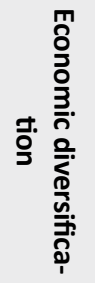 & 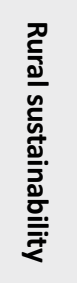 & 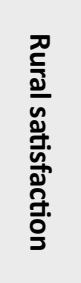 & $\begin{array}{l}\stackrel{\Xi}{\mathbb{D}} \\
\frac{\mathbb{D}}{\mathbb{D}} \\
\frac{\mathbb{D}}{D}\end{array}$ & 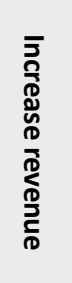 & 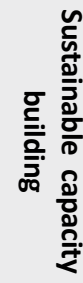 \\
\hline K-S Z & 1.12 & 1.22 & 1.21 & .802 & 1.34 & 1.05 & 1.23 & 1.26 & 1.05 \\
\hline Sig & .161 & .101 & .108 & .540 & .056 & .222 & .098 & .084 & .216 \\
\hline
\end{tabular}

- JSRD

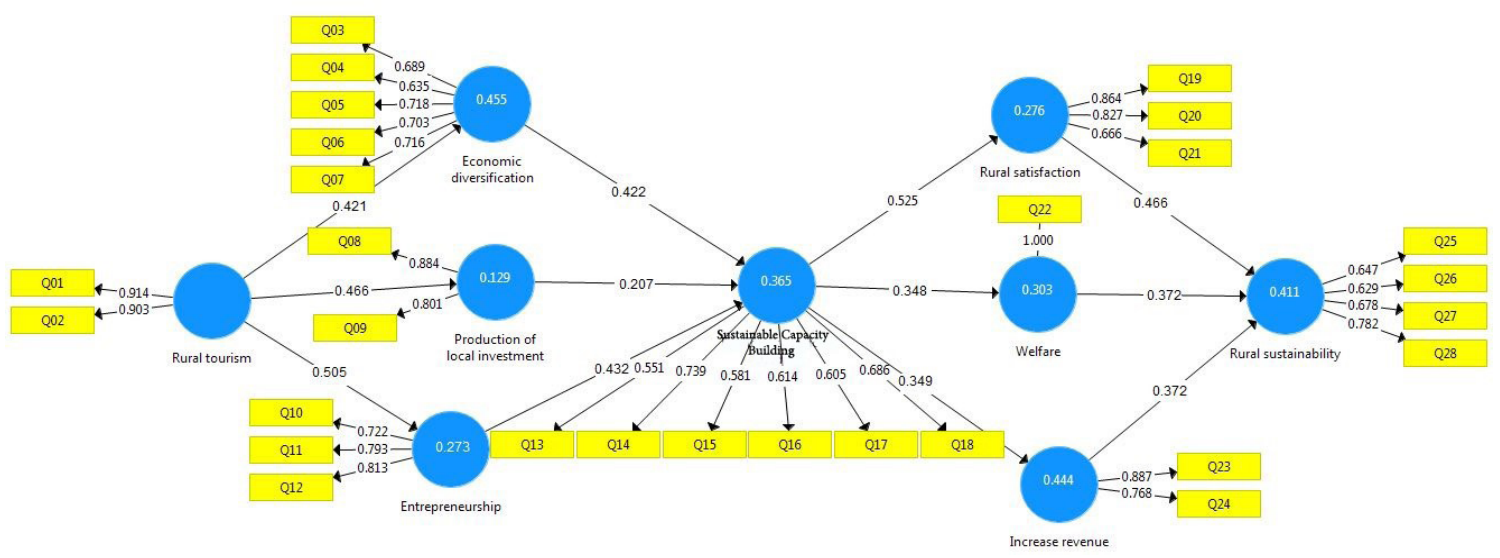

Figure 2. The conceptual model with standard coefficient

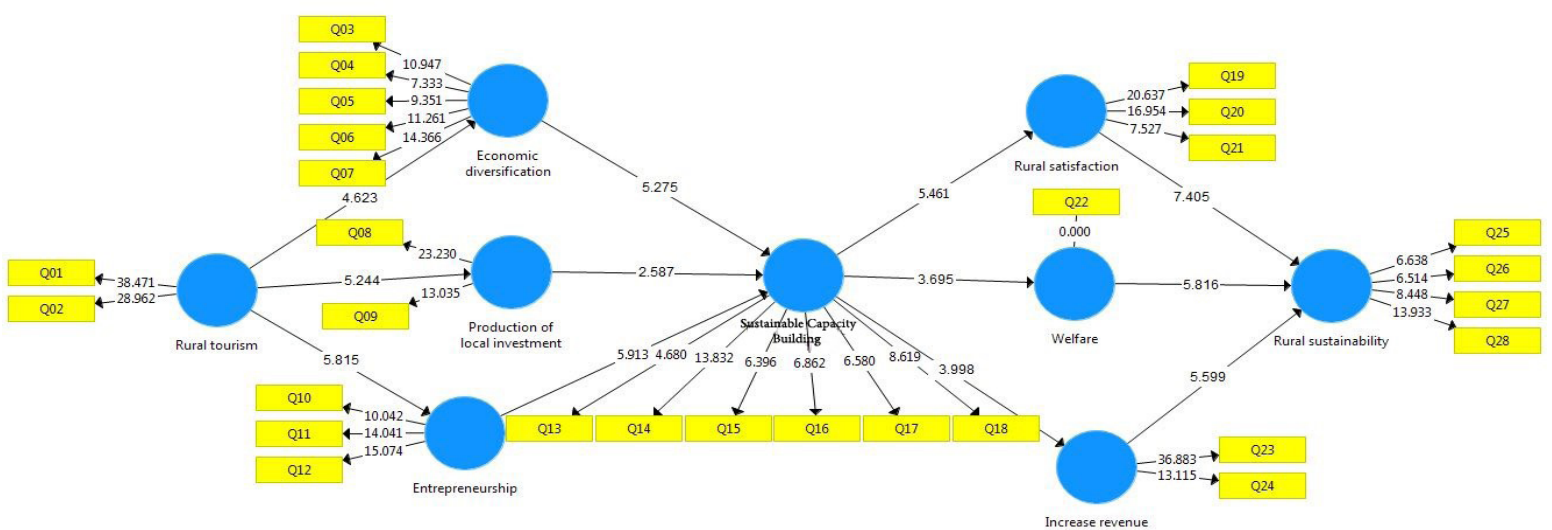

Figure 3. The measurement in PLS structural model

DF was 1.06, while RMSEA was 0.025. These two, along with the other fit indices, were in the acceptable range. It is, therefore, safe to say that the model proved to be appropriate. All the fit indices are provided in Table 5.
The data of the direct and indirect effects, p-values, tvalues as well as the results of the assumptions are presented in Tables 6 and 7.

As shown in Table 6, the p-value for 'the impact of rural tourism on economic diversification' was zero, which 
Table 5. Model fit indices model

\begin{tabular}{ccccccccccc}
\hline $\begin{array}{c}\text { Structural } \\
\text { model }\end{array}$ & p-value & PCFI & PNFI & PRATIO & RFI & IFI & CFI & NFI & RMSEA & X2/df \\
\hline Accepted & $>0.05$ & $0.5<$ & $0.5<$ & $0.5<$ & $0.9<$ & $0.9<$ & $0.9<$ & $0.9<$ & $0.05>$ & $2>$ \\
Calculated & 0.367 & 0.73 & 0.63 & 0.74 & 0.79 & 0.99 & 0.98 & 0.84 & 0.025 & 1.06 \\
\hline & & & & & & & & & & JSRD
\end{tabular}

Table 6. Regression weights of the interrelationship between two sets of variables

\begin{tabular}{|c|c|c|c|c|c|c|c|}
\hline $\begin{array}{l}\text { Independent } \\
\text { variable }\end{array}$ & $\begin{array}{l}\text { Dependent } \\
\text { variable }\end{array}$ & 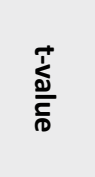 & 京 & 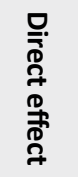 & 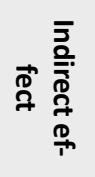 & 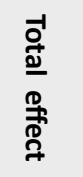 & 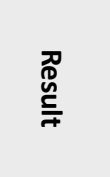 \\
\hline Rural tourism & Economic diversification & 4.623 & .020 & .421 & - & .421 & accept \\
\hline Rural tourism & Production of local investment & 5.244 & $* * *$ & .466 & - & .466 & accept \\
\hline Rural tourism & Entrepreneurship & 5.815 & $* * *$ & .505 & - & .505 & accept \\
\hline Economic diversification & Sustainable capacity building & 5.275 & $* * *$ & .422 & - & .422 & accept \\
\hline $\begin{array}{l}\text { Production of local } \\
\text { investment }\end{array}$ & Sustainable capacity building & 2.587 & .010 & .207 & - & .207 & accept \\
\hline Entrepreneurship & Sustainable capacity building & 5.913 & $* * *$ & .432 & - & .432 & accept \\
\hline $\begin{array}{c}\text { Sustainable capacity } \\
\text { building }\end{array}$ & Welfare & 3.695 & $* * *$ & .348 & - & .348 & accept \\
\hline $\begin{array}{l}\text { Sustainable capacity } \\
\text { building }\end{array}$ & Rural satisfaction & 5.461 & $* * *$ & .525 & - & .525 & accept \\
\hline $\begin{array}{c}\text { Sustainable capacity } \\
\text { building }\end{array}$ & Increase revenue & 3.998 & $* * *$ & .349 & - & .349 & accept \\
\hline Welfare & Rural sustainability & 5.816 & .010 & .372 & - & .372 & accept \\
\hline Rural satisfaction & Rural sustainability & 7.405 & $* * *$ & .466 & - & .466 & accept \\
\hline Increase revenue & Rural sustainability & 5.599 & $* * *$ & .372 & - & .372 & accept \\
\hline Rural tourism & Rural sustainability & 2.355 & .019 & .156 & - & .156 & accept \\
\hline
\end{tabular}

Table 7. The interrelationships of group variables

\begin{tabular}{|c|c|c|c|c|c|c|}
\hline Interrelations of variations & $\frac{\underset{\Phi}{\mathbb{T}}}{\frac{T}{\mathbb{D}}}$ & 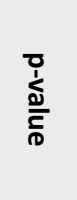 & 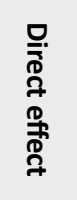 & 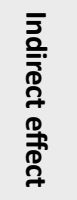 & 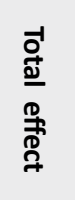 & 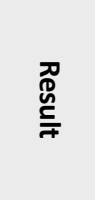 \\
\hline 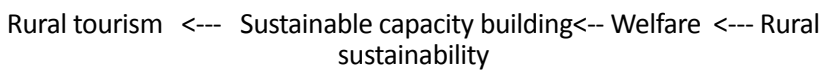 & 2.316 & .020 & .156 & .020 & .180 & accept \\
\hline $\begin{array}{c}\text { Rural tourism } \quad---<\text { Sustainable capacity building }--<\text { increase revenue } \\
---<\text { Rural sustainability }\end{array}$ & 1.100 & .271 & .156 & .010 & .170 & Reject \\
\hline $\begin{array}{c}\text { Rural tourism }<---\begin{array}{l}\text { Sustainable capacity building }<-- \text { Rural satisfaction } \\
<--- \text { Rural sustainability }\end{array}\end{array}$ & 2.372 & .017 & .156 & .020 & .180 & accept \\
\hline
\end{tabular}


is smaller than the $5 \%$ error level. So, the hypothesis was confirmed. It had the standard coefficient of $42 \%$. 'The effects of rural tourism on local investment and entrepreneurship' had a p-value of 0.0001 , much less than 0.05; thus, the hypothesis was confirmed. The standardized coefficients for the two variables showed effects of $47 \%$ and $50 \%$ respectively. Therefore, it can be claimed that rural tourism has the greatest effect on entrepreneurship. The ability of 'economic diversification' and 'local investment' for sustainable capacity building was confirmed with the p-values of 0.0001 and 0.01 respectively. The corresponding standardized coefficients of the three variables showed the effects of $42 \%, 30 \%$ and $21 \%$ respectively. Also, 'economic diversification' was shown to have the greatest impact on sustainable capacity building.

'The effect of sustainable capacity building on rural satisfaction' was $35 \%$ with a p-value of 0.0001 . Also, 'the effect of entrepreneurship on increased revenue' was $33 \%$ with a p-value of 0.0001 . 'The effect of sustainable capacity building on increased revenue' was $35 \%$ with a $\mathrm{p}$-value of 0.0001 . 'The effect of the variables welfare, rural satisfaction and increased revenue on rural sustainability' was confirmed with a p-value of 0.0001 . The standardized coefficients were $37 \%, 47 \%$ and $37 \%$, respectively, meaning that rural satisfaction has the greatest influence on rural sustainability. 'The direct effect of rural tourism on rural sustainability' was $16 \%$ with a p-value of 0.019 . The indirect effects of rural tourism on rural sustainability through economic diversification, sustainable capacity building and welfare all had a p-value of 0.020 . This value was 0.017 for sustainable capacity building and increased revenue through economic diversification confirmed with a standardized coefficient of $2 \%$. The total effect was significant at $18 \%$ (Table 7). The results also showed that rural tourism has had a strong effect on sustainable capacity building in the rural settlements of Shandiz, leading to improved rural sustainability through increased welfare, rural satisfaction, and revenue.

According to the field survey, among the research variables, local investment plays the most important role in creating economic capacity and value added. One of the challenges in rural settlements is transferring money to cities. A lack of funding can hamper expanding productive activities in rural areas, and residents are then forced to migrate. Urban investment is not considered to be a factor that can increase sustainable capacity building because the value added in this type of funding returns to cities and does not ultimately aid rural areas. It is also important for rural areas to create occupations; the villages that could not attract urban investment did not show noticeable economic progress. In this regard, the tourism capabilities of villages are of key importance in attracting funds. Among the sample villages, Virani had the greatest success attracting local funds and rural investment in its industry. It is the home to 50 sofa workshops and exhibitions, all established through the use of local funds and urban tourists who buy sofas from this village. This village has also been the point for urban investment, of course to a lesser degree than local investment. The increase of local funding is the result of the reinvestment of the value added of the production in the village, which has increased noticeably over time. Following Virani, the village of Abardeh Olya village has several workshops established on local funds. The workshops have played a role in developing and strengthening investment in the village because of tourists' shopping. In many other villages, local investments have been concentrated in agriculture, but they have not had the same economic impact.

The absorption of economic capacities is another variant which explains the ability of a village to attract people and rural sustainability. In villages with industrial workshops, many skilled workers have been attracted from towns and cities, which has caused a population growth and created a higher economic capacity for rural diversification and sustainability of the villages. The villages of Virani and Abardeh Olya are considered as unique examples in terms of economic capacities and sustainability. The promotion of sustainable capacity building and rural income has made the youth prefer to stay and live in their own home villages. In this respect, bringing job opportunities to villages plays a key role in the economic development there.

In addition to the creation of job opportunities, the increase of services plays a major role in promoting economic capacity too. One of the services to provide in tourist villages is restaurants, the variety of which depends on the number and taste of tourists. In the area being examined, of all the villages, Abardeh Olya and Zoshk have the largest numbers of host units as well as many cafes and restaurants. These restaurants have become the chief tourist attraction of those villages, and some tourists visit simply to eat there, including many tourists from the neighbouring Arab countries. Most of these restaurants were established through urban investment, which encouraged the creation of lateral jobs such as transportation services and local cafes. Thus, rural tourism impacts the development of economic sectors in rural regions. Concentrating on a single aspect of rural economy creates challenges, so it is crucial to build up a 
diverse economy on the purpose of promoting rural sustainability.

\section{Discussion}

Undoubtedly, tourism is a major phenomenon that can create new opportunities in rural regions. The regions are endowed with many unique landscapes that attract urban residents, especially those from metropolitan regions. Urban problems such as air pollution and noise have made rural locations popular destinations. In addition, rural settlements experience many economic constraints that tourism can help to eradicate. One of the challenges of those areas is depopulation. In this regard, tourism can assist in creating sustainable settlements through new establishments and functions that have a considerable impact on the regional economy and spatial networks. These networks connect rural economies to large-scale economies at national and international levels. Villages have the potential to absorb international tourists, which will influence regional income. The main attraction of rural tourism in Shandiz region is the varied natural phenomena. The diverse economic sectors in this region can also serve as an appeal to tourists. In this case, tourism is approached as a series of opportunities that lead to an increasing number of commercial transactions. Tourism's power to bolster small and medium-sized enterprises demonstrates that tourism is a key element in poverty reduction, and significant local investments in it can ultimately contribute to rural transformation. Tourism has already improved the economic status of Shandiz, and, therefore, should be considered as a tool for development. To achieve the goals of rural sustainability, various institutions should make effective policies that meet the job expectations of the youth, the outcome of which will be a low unemployment rate and a high percentage of workforce participation. According to the field findings, a high percentage of the rural young workforce does a variety of jobs to make a living. Tourism also provides a way to raise funds. Rural tourism increases local capital flows and urban investment. It is also a tool for entrepreneurship and development of small rural manufacturing centers that provide value added for rural residents, Thereby, local economic diversification is enhanced, and services are improved. The promotion of diverse economic sectors is highly significant to producing economic capacity. Therefore, it should be given the attention that it deserves.

\section{Acknowledgements}

This research did not receive any specific grant from funding agencies in the public, commercial, or not-forprofit sectors.

\section{Conflict of Interest}

The authors declared no conflicts of interest.

\section{References}

Abubakaria ,Z., van der Molen, P., Bennett, R.M., Kuusaana, E.D (2016). Land consolidation, customary lands, and Ghana's Northern Savannah- Ecological Zone: An evaluation of the possibilities and pitfalls. Land Use Policy 54(5):386-398.

Anabestani,A. \& Vesal,Z.(2016). [The analysis of effective elements on tourism branding on rural settlements( the case study: Binalood county) (Persian)].Planning \& Tourism development, 16(1),127-148.

Anderson, E., Bakir, A., \& Wickens, E. (2015). Rural tourism development in Connemara, Ireland. Tourism Planning and Development, 12(1), 73-86.

Ashley, C., Roe, D., \& Goodwin, H. (2001). Pro-poor Tourism Strategies: Making Tourism Work for the Poor: A Review of Experience. London: Overseas Development Institute.

Bianchi, R. (2004). Tourism restructuring and the politics of sustainability: A critical view from the European periphery (the Canary Islands). Journal of Sustainable Tourism, 12(6), 495-529.

Biddulph,R. (2015). Limits to mass tourism's effects in rural peripheries. Annals of Tourism Research, 50 (1), 98-112.

Blanco, F.J. (1996). Fundamentos de la política comunitaria y española en material de turismo rural: Consideraciones sobre la legislación española [Foundations of community and Spanish policies in rural tourism: Considerations on Spanish legislation]. Estudios Turísticos,131, 25-68.

Bramwell, B. (2004). Mass tourism, diversification and sustainability in Southern Europe's coastal regions. In B. Bramwell (Ed.), Coastal mass tourism: Diversification and sustainable development in Southern Europe :Channel View Publications.

Burns, P. \& Novelli ,M. (2007). Tourism \& Politics:Global Framework \& Local Realities. London: Routledge.

Butler, R. W., \& Hall, C. M. (1998). Conclusion: The sustainability of tourism and recreation in rural areas. In R. W. Butler, C. M. Hall, \& J. Jenkins (Eds.), Tourism and recreation in rural areas (pp. 249-258). Chichester, UK: John Wiley.

Bygrave, W. D. (1993). Theory building in the entrepreneurship paradigm. Journal of business Venturing, 8(3) , 255-280.

Campón-Cerro, A.M., Hernández-Mogollón, J.M., Alves, H. (2016). Sustainable improvement of competitiveness in rural 
tourism destinations: The quest for tourist loyalty in Spain. Journal of Destination Marketing \& Management, 5(2), 1-15.

Cantallops, A. S., Cardona, J. R., \& Muntaner, R. E. (2015). Characteristics and peculiarities of rural tourism in the Balearic Islands. Tourism Planning \& Development, 12(2), 122-144.

Cater, E. A. (1987). Tourism in the least developed countries. Annals of Tourism Research, 14(2), 202-226.

Cawley, M., Gaffey, S., \& Gillmor, D. A. (2002). Localisation and global reach in rural tourism: Irish evidence. Tourist Studies,2(1), 63-86.

Chaslzin, R.J., Brown, P.,Venlzatesh, S., \& Vidal, A. (2001). Building Community Capacity. New York: Aldine de Gruyter.

Chemin, M. (2008). The Impact of the Judiciary on Entrepreneurship: Evaluation of Pakistan's Access to Justice Programme. Journal of Public Economics, 93(1), 114-125.

Crotts ,J \& Holland,S. (1993). Objective indicators of the impact of Rural Tourism Development in the State of Florida. Journal of Sustainable Tourism,1(2),112-120.

De Kadt, E. (1979). Tourism. Passport to development? .New York: Oxford University Press.

Deegan, J., \& Dineen, D. J. (2003). The changing contribution of tourism in a dynamic economy: The case of Ireland. Tourism Economics, 9(2), 147-164.

Demetrious, D., Stillwell, J., See, L. (2013).A new methodology for measuring land fragmentation. Computers. Environment and Urban Systems, 39(3): 71-80.

Démurger, S., Fournier ,M. ,\& Yang, W. (2010). Rural households' decisions towards income diversification: Evidence from a township in northern China. China Economic Review, 21(1), 32-44

Dwyer,L., Forsyth, P., \& Papatheodorou, A. (2011). Economics of Tourism. Oxford: Contemporary Tourism Reviews.

Dyer, P., Gursoy,D., Sharma,B.\&\& Carter,J. (2007). Structural modeling of resident perceptions of tourism and associated development on the Sunshine Coast, Australia. Tourism Management, 28(2), 409-422.

Ezeuduji, I. (2015). Strategic event-based rural tourism development for sub-Saharan Africa. Current Issues in Tourism,18(3), 212-228.

Fennell, D. (2008). Ecotourism. London: Routledge.

Flanigan,S.,Blackstock ,K.,\& Hunter,C. (2014). Agritourism from the perspective of providers and visitors: a typology-based. Tourism Management, 40(1): 394-405.

Frisvoll, S. (2012). Power in the production of spaces transformed by rural tourism. Journal of Rural Studies, 28 (4),447-457.

Garrod, B., Wornell, R., \& Youell, R. (2006). Re-conceptualizing rural resources as countryside capital: The case of rural tourism. Journal of Rural Studies, 22(1), 117-128.

Gautam ,Y., \& Andersen , P. (2016). Rural livelihood diversification and household well-being: Insights from Humla, Nepal. Journal of Rural Studies, 44(1): 239-249
Ghanian, M., Ghoochani, O.,\& Crott ,J. (2017). Analyzing the Motivation Factors in Support of Tourism Development: The Case of Rural Communities in Kurdisan Region of Iran. Journal of Sustainable Rural Development, 1(2):137-148.

Gil Arroyo, C., Barbieri , C., \& Rozier Rich ,S. (2013). Defining agritourism: A comparative study of stakeholders' perceptions in Missouri and North Carolina.Tourism Management, 37(4), 39-47.

Guaita Martínez, J. M., Martín Martín, J. M., Salinas Fernández, J. A., \& Mogorrón-Guerrero, H. (2019). An analysis of the stability of rural tourism as a desired condition for sustainable tourism. Journal of Business Research, 100(7), 165-174.

Gursoy, D., \& Rutherford ,D. (2003). Host attitudes toward tourism, an improved structural model, Annals of Tourism Research, 31(3), 495-516.

Haase Svendsen, G., Kjeldsen, C., \& Noe,E. (2010). How do private entrepreneurs transform local social capital into economic capital? Four case studies from rural Denmark. Journal of Socio-Economics, 39(6), 631-644.

Hall, D., Kirkpatrick, I., \& Mitchell, M. (2005). Rural tourism and sustainable business. Ontario, Canada: Channel View Publication.

Harrison,J. (2001). Thinking about tourists. International sociology,16 (2),159-172.

Helmi Ali,M.,\& Suleiman, N. (2016). Sustainable food production: Insights of Malaysian halal small and medium sized. International Journal of Production Economics,176(6),1-12 .

Hernandez, J.M., Suarez-Vega, R.,\& Santana-Jimenez,Y. (2016). The inter-relationship between rural and mass tourism: The case of Catalonia, Spain. Tourism management, 54(3), 43-57.

Hesam, M., \& Rezvani, M.R. (2017). [Recognition and analysis of network relations in rural tourism through grounded theory: A case study on mountainous valley route of Haraz, Iran (Persian)]. Journal of Sustainable Rural Development, 1(1), 39-52.

Hoefle, S. W. (2016) .Multi-functionality, juxtaposition and conflict in the Central Amazon: Will tourism contribute to rural livelihoods and save the rainforest? Journal of Rural Studies, 44(2), 24-36.

Holland, G., Burian, M. and Dixey, L. (2003). Tourism in Poor Rural Areas: Diversifying the Product and Expanding the Benefits in Rural Uganda and the Czech Republic, PPT working paper, No. 12.

Hounslow,B. (2002). Community capacity explained. Stronger Families Learning ExchangeBulletin, 1, 20-22.

Hwang,J.H.,\& Lee ,S.W. (2015). The effect of the rural tourism policy on non-farm income in South Korea, Tourism Management, 46(1),501-513.

IIbery, B. (1998). The geography of rural change. Harlow, UK: Longman.

Ionela,G.-P.,Constantin ,B. M.,\& Dogaru ,L.D. (2015). Advantages and Limits for Tourism Development in Rural Area (Case Study Ampoi and Mures Valleys), Procedia, Economics and Finance,32,1050-1059.

Jaafar,Mastura, Rasoolimanesh ,S. Mostafa, Tuan Lonik, Ku' Azam. (2015) Tourism growth and entrepreneurship: Empiri- 
cal analysis of development of rural highlands, Tourism Management Perspectives, 14(2) ,17-24.

James, V.U. (1998). Capacity Building in Developing Countries. London: Praeger.

Jenkins, T., \& Parrott, N. (1997). Regional images and the promotion of quality products and services in the lagging regions of the European Union. Aberystwyth, UK: Welsh Institute of Rural Studies.

Kenny, S., \& Clarke, M. (2010). Challenging capacity buildingcomparative perspectives. New York: Palgrave Macmillan.

Kroshus Medina, L. (2005). Ecotourism and certification: confronting the principles and pragmatics of socially responsible tourism. Journal of sustainable tourism, 13(3),281-295.

Lavarack,G. (2006). Evaluating community capacity: visual representation and interpretation. Community Development Journal, 41(3), 266-276.

Li, Ping, Ryan, Chris, Cave, Jenny. (2016). Chinese rural tourism development: Transition in the case of Qiyunshan, Anhui, 2008-2015.Tourism Management, 55(4) , 240-260.

Liu, A. (2006). Tourism in rural areas: Kedah, Malaysia. Tourism Management, 27(5), 878-889.

Lo, M-C., Mohammad,A.,Songan, P., \& Yeo, A.W. (2012). Positioning rural tourism: perspectives from the local communities, International Journal of Trade, Economics \& Finance, 3(1), 59-65.

Lopez, Miriam, \& Pastor, R. (2015). Development in rural areas through capacity building and education for business, 7th World Conference on Educational Sciences, Novotel Athens Convention Centre: Athens, Greece, In Procedia - Social and Behavioral Sciences, 197, 1882 - 1888.

Martin, S.M., \& Lorenzen, K. (2016). Livelihood Diversification in Rural Laos. World Development, 83(7): 231-243.

Mitchell, J., \& Ashley, C. (2010). Tourism and poverty reduction: Pathways and prosperity. London: Earthscan.

Moloney ,S., \& Fünfgeld , H. (2015). Emergent processes of adaptive capacity building: Local government climate change alliances and networks in Melbourne. Urban Climate , 14 (4) $: 30-40$.

Moscardo, G. (2008). Building community capacity for tourism development .London: Cabi Publishing.

Mowforth, M., \& Munt, I. (2009). Tourism \& sustainability: Development globalization \& new tourism in the third world. Third Edition, Abington, UK: Routledge.

Murty, S. A. (2004). Mapping community assets: the key to effective rural social work . In L. Scales \& C.Streeter, Rural social work: Building assets to sustain rural communities, 278-289. Belmont, CA: Brooks/Cole/Thomson Learning.

Mwesigye, F., \& Matsumoto, T. (2016). The effect of population pressure and internal migration on land conflicts: Implication for agriculture Productivity in Uganda. World Development, 79(3), 25-39.

Myers, N. (2003). Conservation of biodiversity: how are we doing? Environment system \& decision , 23(1), 9-15.
Naidoo, P.,\& Sharpley ,R. (2016). Local perceptions of the relative contributions of enclave tourism and agritourism to community well-being: The case of Mauritius. Journal of Destination Marketing \& Management ,5(1): 2-16.

Nair, V., Munikrishnan, U. T., Rajaratnam, S. D., \& King, N. (2015). Redefining rural tourism in Malaysia: A conceptual perspective. Asia Pacific Journal of Tourism Research, 20(3), 314-337.

Napton, D., Walford, N., \& Everitt, D. (1999). Continuity and change in the developed countryside. In N. Walford, J. Everitt, \& D. Napton (Eds.), Reshaping the countryside: Perceptions and processes of rural change (pp. 1-11). Wallingford, UK: CABI.

Nourozifard, H., \& Khorasani,M.A. (2016). [Strategic Planning of rural tourism development in rural regions of Izeh-Iran, The case study : Shivand village(Persian)]. Geography \& urban-regional preparation, 18(1), 119-134.

Plummer, J. \& Taylor, J.G. (2004). Community participation in China, Issues \& Processes for Capacity Building.UK: Earthscan.

Reardon, T., Delgado, C., \& Matlon, P. (1992). Determinants and effects of income diversification amongst farm households in Burkina Faso. Journal of Development Studies, 28 (2),264-296.

Russell, R., \& Faulkner, B. (1999). Movers and shakers: Chaos makers in tourism development. Tourism Management, 20(4), 411-423.

Russell, R., \& Faulkner, B. (2004). Entrepreneurship, chaos and the tourism area life cycle. Annals of Tourism Research, 31(3) $556-579$.

Ryan, C., Gu, H., \& Zhang, W. (2009). The context of Chinese tourism - an overview and implications for research. In C. Ryan, \& H. Gu (Eds.), Tourism in China: Destination, cultures and communities, 327-336, New York: Routledge.

Sánchez-Rivero, M., \& Cárdenas-García, P.J. (2014). Population characteristics \& the impact of tourism on economic development. Tourism Geographies, 16(4), 615-635.

Saxena, G., Clark, G., Oliver, T., \& Illbery, B.(2007). Conceptualizing integrated rural tourism. Tourism Geographies, 9(4), 347-370.

Scales, T.L., Streeter, C.L., \& Cooper, H.S. (2014). Rural Social Work: building \& sustaining community capacity. USA: Wiley.

Sharpley, R. (2002). Rural tourism and the challenge of tourism diversification: the case of Cyprus. Tourism Management, 23(3), 233-244.

Sharpley, R., \& Telfer, D. J. (2015). Tourism and development. Toronto: Channel View Publications.

Silva,L., \& Leal, J. (2015). Rural tourism and national identity building in contemporary Europe: evidence from Portugal, Journal of Rural Studies ,38 (2), 109-119.

Soleimani, M., Bozarjomehri, K., Javan,J., \& Anabestani,A (2015). [The analysis of effective elements on rural unsustainability -Iran (Persian)]. Research and rural planning, 4(11) , 21-38. 
StataCorp. (2011). Structural equation modeling: Reference manual. College Station, TX: Stata Press.

Steiner, A., \& Atterton, J. (2015). Exploring the contribution of rural enterprises to local resilience. Journal of Rural Studies, $40(3), 30-45$

Taleshi, M., \& Amirfakhriyan, M. (2011). [Rural unsustainability $\&$ the future of marginalisation in Khorasan Razavi (Persian)] Geography,29(3),83-107.

Telfer, D.J. \& Sharpley ,R. (2008). Tourism \& development in the developing world. New York: Routledge.

Tew, C., \& Barbieri ,C. (2012). The perceived benefits of agritourism: The provider's perspective. Tourism Management, 33(1), 215-224.

Torres-Delgado, A., \& Saarinen, J. (2014). Using indicators to assess sustainable tourism development: A review. Tourism Geographies, 16(1), 31-47.

Tosun, C. (2002). Host perceptions of impacts: A comparative tourism study. Annals of Tourism Research, 29 (1), 231-253.

Weaver, B. (2001). Ecotourism. Sydney, Australia: Wiley.

Zamora, O. M. (2011). Development Instruments for the CrossBorder Cooperation in Ukraine, In: Problems of tourism development on rural areas, Krystyna Krzyzanowska (ed.)., Warsaw: Warsaw University of Life Sciences Press.

Zasada ,I., \& Piorr ,A. (2015). The role of local framework conditions for the adoption of rural development policy: An example of diversification, tourism development and village renewal in Brandenburg Germany. Ecological Indicators, 59(12): 82-93.

Zasada ,I.,Reutter, M., Piorr, A.,Lefebvre, M., \& Paloma, S.G. (2015). Between capital investments and capacity building Development and application of a conceptual framework towards a place-based rural development policy. Land Use Policy, 46 (5) ,178-188.

Zeng, G. (2015). Tourism and hospitality development between China and EU. New York, NY: Springer.

Zhang ,Q., Sun, Z. ,Wu, F.,\& Deng, X. (2016). Understanding rural restructuring in China: The impact of changes in labor and capital productivity on domestic agricultural production and trade. Journal of Rural Studies, 47(6), 552-562.

Zhao, W., Ritchie, J. R., \& Echtner, C. M. (2011). Social capital and tourism entrepreneurship. Annals of Tourism Research, 38(4), 1570-1593. 
